\title{
KARAKTERISTIK ZONASI BATUAN RESERVOAR BERDASARKAN PETROGRAFI, SERBUK BOR, UJI TEKANAN DAN TEMPERATUR \\ DI LAPANGAN PANAS BUMI SOKORIA, KABUPATEN ENDE, PROVINSI NUSA TENGGARA TIMUR
}

\section{RESERVOIR CHARACTERISTICS BASED ON PETROGRAPHY, CUTTING, PRESSURE AND TEMPERATURE TEST IN SOKORIA GEOTHERMAL FIELD, ENDE REGENCY, NUSA TENGGARA TIMUR PROVINCE}

\author{
Aldila Jasmine Purbiyantoro, Agus Didit Haryanto, \\ Euis Tintin Yuningsih, dan Haris Siagian \\ Fakultas Teknik Geologi Universitas Padjadjaran, Sumedang \\ aldila14001@mail.unpad.ac.id
}

\begin{abstract}
ABSTRAK
Lapangan Panas Bumi Sokoria terletak di Desa Sokoria, Kabupaten Ende, Provinsi Nusa Tenggara Timur. Penelitian ini bertujuan untuk mengetahui karakteristik zonasi secara vertikal batuan penudung, transisi dan reservoar pada sumur W-1 dan W-2. Pendekatan yang digunakan adalah analisis petrografi dan analisis metilen biru (MeB) untuk mengetahui rasio ilit-smektit dan kehadiran mineral alterasi dalam batuan sebagai indikator batas zona batuan penudung, transisi dan reservoar. Uji tekanan dan temperatur ( $P \& T$ Test) juga digunakan sebagai panduan dalam penentuan zonasi. Hasil yang didapat bahwa zona penudung panas bumi berada dari permukaan hingga kedalaman $700 \mathrm{mVD}$ (meter vertical depth), dibuktikan oleh indeks MeB sedang - tinggi $(20-80 \%)$ penciri smektit serta temperatur batuan sekitar $100^{\circ} \mathrm{C}$. Zona transisi berada dari kedalaman $700 \mathrm{mVD}-1100 \mathrm{mVD}$, dibuktikan oleh indeks MeB rendah $(6-20 \%)$ sebagai penciri ilit dan ilit-smektit serta temperatur uji mencapai $200^{\circ} \mathrm{C}$. Zona reservoar berada pada kedalaman $1100 \mathrm{mVD}$, dicirikan oleh indeks MeB sangat rendah $(<10 \%)$ sebagai penciri ilit serta kemunculan epidot pada sumur W-1 di kedalaman $1119 \mathrm{mMD}$ (meter measured depth) dan sumur W-2 di kedalaman 1338 mMD, uji P\&T menunjukkan temperatur reservoar dapat mencapai $250^{\circ} \mathrm{C}$.
\end{abstract}

Kata kunci: Sokoria, metilen biru, petrografi, uji P\&T, mineral alterasi

\begin{abstract}
Sokoria Geothermal Field is located at Sokoria Village, Ende Regency, Nusa Tenggara Timur Province. Petrographic analysis and Methylene Blue test $(\mathrm{MeB})$ were carried out to estimate the illite-smectite ratio and occurence of other alteration minerals as indicator for cap rock, transition and reservoir zones. Pressure and temperature test (P\&T test) was also performed to determine those zonation. The result concludes the geothermal caprock zone is distributed from the surface to the dept of $700 \mathrm{mVD}$ (meter vertical depth), indicated by medium to high $\mathrm{MeB}$ index $(20-80 \%)$, as smectite characteristic temperature up to $100^{\circ} \mathrm{C}$. The transition zone is located from the depth of $700 \mathrm{mVD}$ to $1100 \mathrm{mVD}$, with low MeB index (6-20\%), as illite and illite-smectite characteristic and well temperature up to $200^{\circ} \mathrm{C}$. Reservoir zone is located at $1100 \mathrm{mVD}$, indicated by very low $\mathrm{MeB}$ index (<10\%), as characteristic of illite, with first appearance of epidote in well W-1 at 1119 mMD (meter measured depth) and well W-2 at $1338 \mathrm{mMD}$. P\&T test shows reservoir temperature reached $250^{\circ} \mathrm{C}$.
\end{abstract}

Keywords: Sokoria, methylene blue, petrographic, P\&T test, alteration mineral 


\section{MAKALAH ILMIAH}

\section{PENDAHULUAN}

Pulau Flores yang telah ditetapkan dengan Kepmen ESDM No.2268 K/30/MEM/2017 sebagai Flores Geothermal Island, memiliki total potensi energi panas bumi sebesar $902 \mathrm{MW}$ atau $65 \%$ dari potensi panas bumi yang ada di provinsi Nusa Tenggara Timur (NTT).

Daerah potensial tersebut adalah Waisano, Ulumbu, Sokoria, Wai Pesi, Mataloko, Oka Ile Ange, Atadei, Komandaru, Jopu, Mengeruda, Ndetusoko, Lesugolo, Bukapiting, Roma-Ujelewung, Oyang Barang, dan Gou-Inelika. Hingga saat ini baru Ulumbu dan Mataloko yang sudah dimanfaatkan untuk pembangkit listrik oleh PLN (Suparman, 2009).

Sumur $\mathrm{W}-1$ dan $\mathrm{W}-2$ yang berada dalam wellpad A yang merupakan bagian dari sumur eksplorasi di lapangan panas bumi Sokoria, Kabupaten Ende, Provinsi NTT, merupakan objek yang diteliti. Tujuan dari penelitian ini difokuskan untuk mengetahui karakteristik zonasi sistem panas bumi secara vertikal dari sumur W-1 dan W-2. Sumur tersebut terletak pada wellpad A (Gambar 1) yang dekat dengan hidrotermal aktif, seperti fumarol, mata air panas, dan mata air hangat, yang diduga memiliki perkiraan temperatur reservoar yang tinggi dan permeabilitas baik (Harvey et al., 2000).

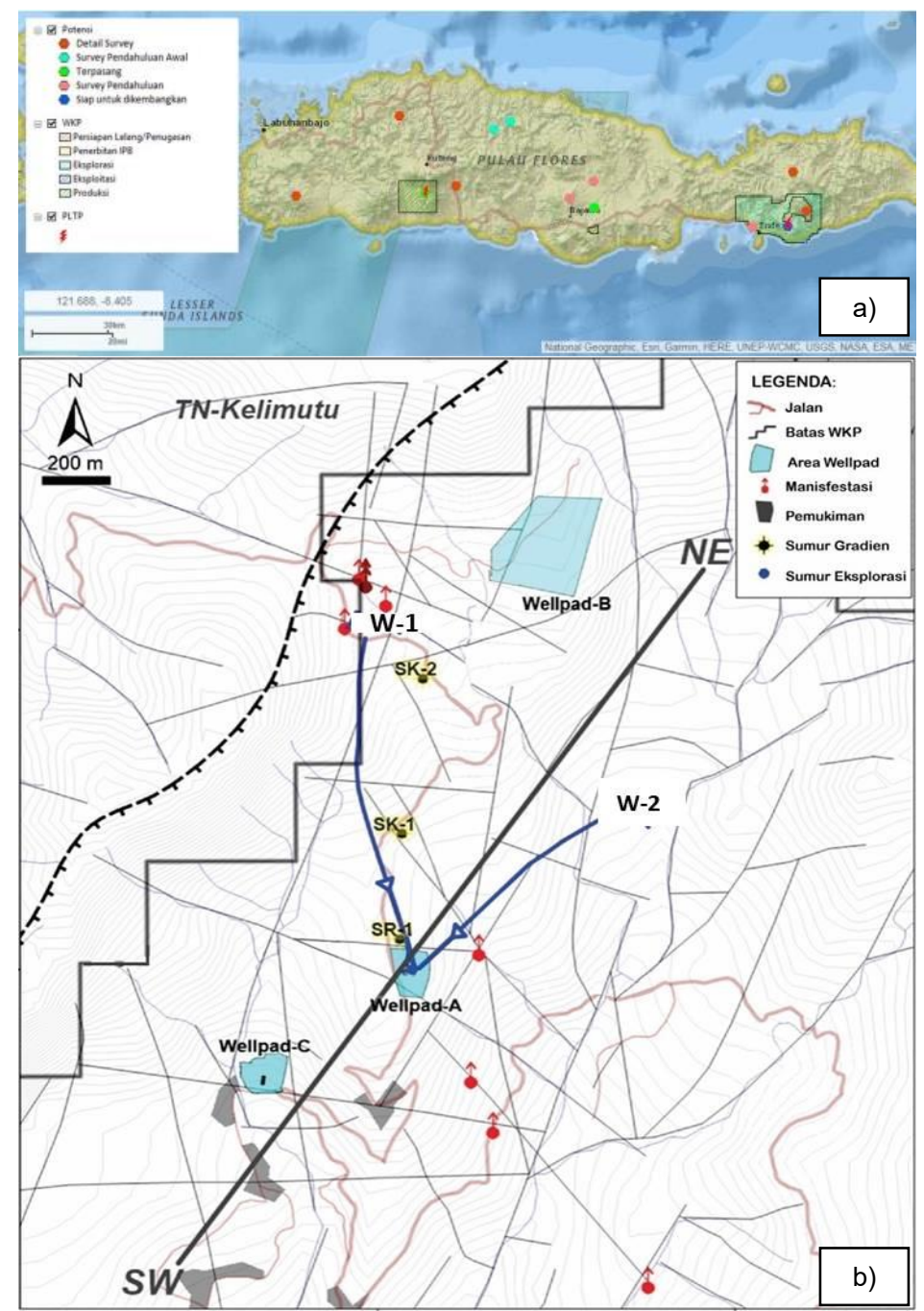

Gambar 1. a) Lokasi WKP Sokoria di Pulau Flores (http://igis.esdm.go.id/igis/potensi/index) dan b) Peta situasi lokasi wellpad A area Sokoria. W-1 dan W-2 adalah sumur penelitian (Modifikasi dari Sarmiento et al., 2019) 


\section{Geologi Regional}

Zona fisiografi daerah NTT termasuk ke dalam wilayah Kepulauan Sunda Kecil yang terbentang dari Pulau Bali hingga Pulau Wetar (van Bemmelen, 1949). Kepulauan Sunda Kecil merupakan gugusan kepulauan dengan penyusun batuan produk busur vulkanik. Sementara itu, Pulau Flores termasuk ke dalam inner arc bagian timur dari Kepulauan Sunda Kecil.

Kompleks Gunungapi Kelimutu dibentuk oleh serangkaian fase erupsi, yaitu, yang tertua adalah andesit berumur Tersier yang terekspos di lereng gunung berapi yang lebih rendah, diikuti oleh pembentukan awal gunungapi andesitik Sokoria Kuarter di bagian baratlaut nya dan kemudian runtuh membentuk kaldera. Selanjutnya terbentuk gunungapi Keli Bara di bagian selatan dengan lava andesit dan batuan piroklastik mengisi fitur runtuhan sebelumnya. Fase terakhir berpusat pada Gunungapi Kelimutu, dimana danau kawah asamnya mencerminkan aktivitas sistem hidrotermal yang besar di gunungapi tersebut (Harvey et al., 2000).

Di konsesi WKP PT. Sokoria Geothermal Indonesia, manifestasi permukaan panas bumi terbagi menjadi manifestasi air panas dan gas (fumarol-solfatara). Manifestasi air panas muncul pada beberapa area yaitu: area Sokoria, Detupetu, Wolobara; Area Waturaka Liasambe; Area Woloveo, Detusoko, Ae Ria; Area Roga, Jopu. Sementara manifestasi gas terletak pada area, yaitu: Area Mutubusa dan Area Mutulo'o.

\section{Geologi Daerah Sokoria}

Secara umum daerah lapangan panas bumi Sokoria di batasi dan dikontrol oleh kaldera yang merupakan hasil dari erupsi gunungapi dan hidrotermal aktif (Harvey et al., 1998). Struktur utama yang berkembang di Sokoria adalah Sesar Lawongalopolo. Sesar ini berarah relatif utara timurlaut - selatan baratdaya (Sarmiento et al., 2019).

Mengacu kepada Sarmiento et al., 2019, stratigrafi daerah lapangan panas bumi Sokoria yang berada di sisi baratdaya Kompleks Gunungapi Kuarter Kelimutu merupakan bentukan dari hasil Gunungapi Muda Kelimutu dengan dominasi batuan vulkanik berupa andesit dengan dasit di bawahnya. Terdapat tiga unit stratigrafi di Sokoria dari umur tua ke muda, yaitu (Gambar 2):

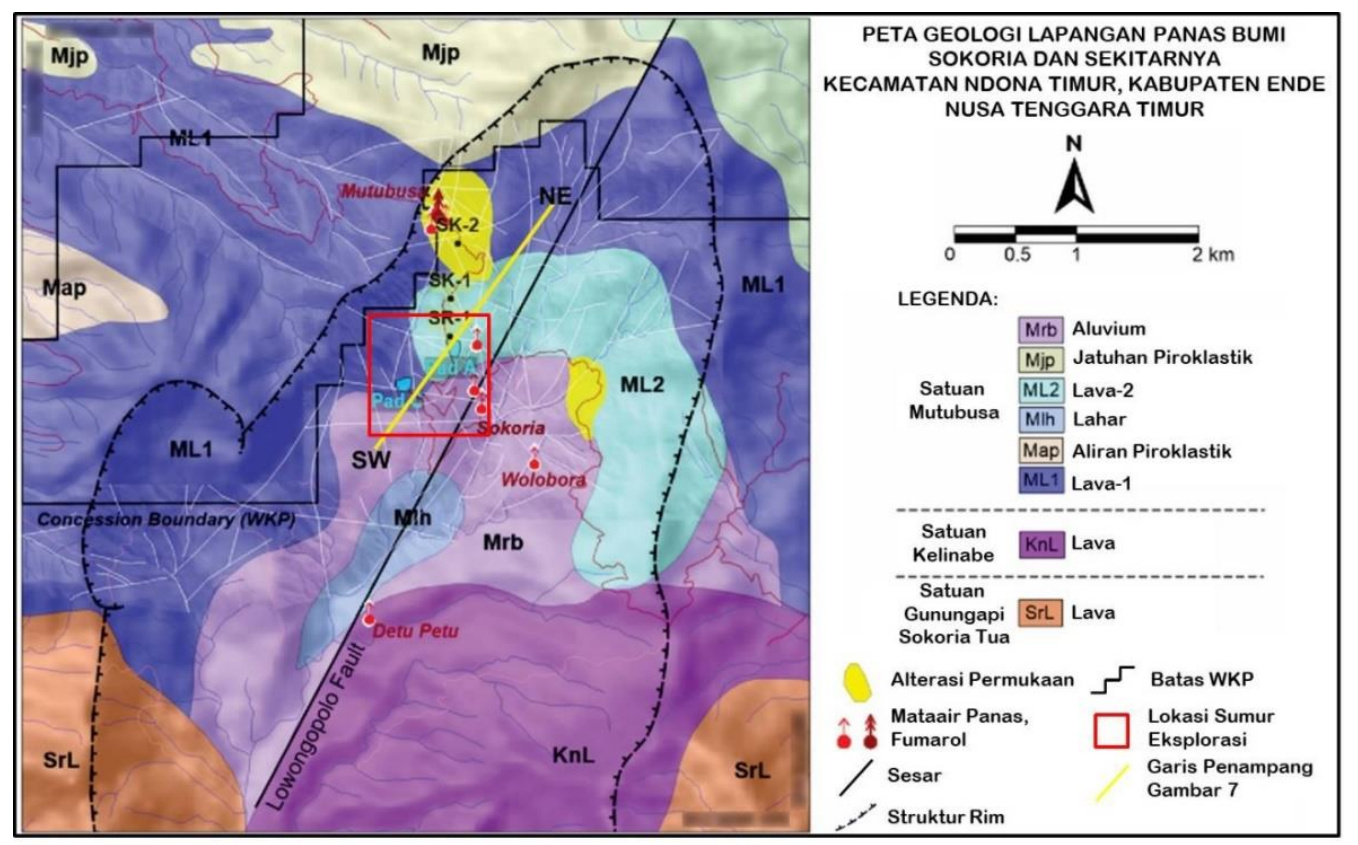

Gambar 2. Peta Geologi Lapangan Panas Bumi Sokoria

(Modifikasi dari Sarmiento et al., 2019) 


\section{Satuan Gunungapi Sokoria Tua}

Litologi Gunungapi Sokoria Tua ini terdiri dari kontak batuan piroklastik teralterasi, tuf litik tuf breksi, batuan piroklastik andesit, dan breksi teralterasi, alterasi sedang hingga kuat dominasi silika dan klorit, sedikit peningkatan mineral epidot.

\section{Satuan Kelinabe}

Litologi Kelinabe terdiri dari tuf litik dan tuf kristal litik, dengan fragmen batuan andesitik, alterasi sedang hingga kuat. Klorit sebagai pengganti massadasar di litik andesit. Semen kalsit, veinlet, dan ilit terdapat di massa dasar klorit.

\section{Satuan Mutubusa}

Litologi Mutubusa didominasi oleh perselingan lava dan piroklastik. Satuan ini terdiri dari lava andesit, tuf breksi, tuf litik. Fragmen piroklastik terdiri dari litik tuf, andesit, dan dasit. Bentuk fragmen menyudut hingga menyudut tanggung, alterasi lemah hingga sedang. Pada endapan piroklastik ini temukan manifestasi batuan terubah (Hochstein et al., 2010).

\section{Geokimia Daerah Sokoria}

Manifestasi permukaan panas bumi yang muncul di daerah Sokoria berupa fumarol, mata air panas, dan tanah panas (steaming ground) yang tersebar di Mutubusa, bagian utara prospek Sokoria (Gambar 3) dan sekitar lereng Gunung Kelimutu. Manifestasi yang paling terkenal adalah danau tiga warna (merah, hijau, dan biru) yang berada pada kawah Gunungapi Kelimutu.

Diagram ternary $\mathrm{Cl}-\mathrm{SO}_{4}-\mathrm{HCO}_{3}$ (Giggenbach, 1991) digunakan untuk mengetahui tipe air panas bumi dengan cara memplot komposisi unsur $\mathrm{Cl}^{-}, \mathrm{SO}_{4}{ }^{2-}$ , dan $\mathrm{HCO}_{3}{ }^{-}$ke diagram. Hasil plot pada diagram tersebut yang dilakukan oleh Sarmiento et al., 2019, menunjukkan tipe air panas dari danau Kelimutu Jopu, dan Toba berada di antara sudut sulfat dan klorida yang mengindikasikan air mengandung komponen asal vulkanik. Sementara itu, air panas Detusoko berada pada steam heated acid sulfate water, yang diinterpretasikan memiliki tipe air sulfat yang sudah terpanaskan. Hasil plot air panas Detupetu, Wolobora, dan Jopu bertipe air klorida. Hasil plot air panas Sokoria, Saga, Waturaka, Woloeo, Ae Melo, dan Liasembe bertipe air bikarbonat, seperti terlihat pada gambar 4 (Nicholson, 2012).

Hasil studi literatur yang di dapat, pendugaan temperatur reservoar bawah permukaan yang dihitung menggunakan geotermometer gas daerah Sokoria dan sekitarnya menunjukkan kisaran temperatur $210-250^{\circ} \mathrm{C}$ (Sarmiento et al., 2019).

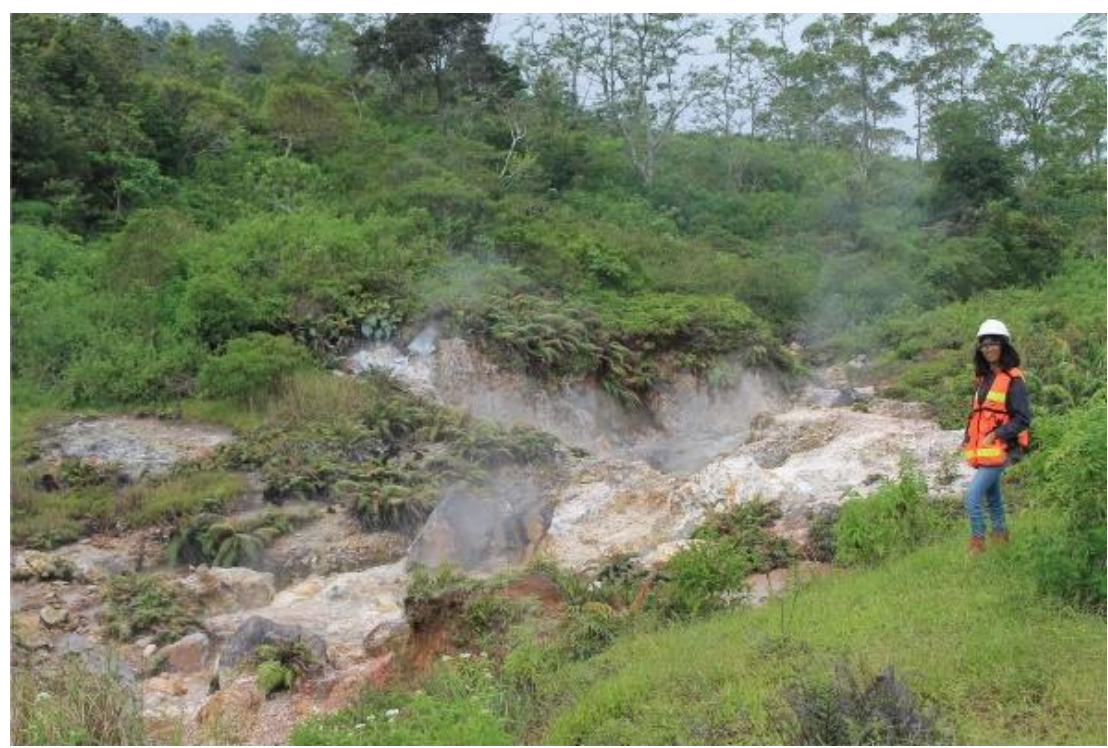

Gambar 3. Manifestasi permukaan panas bumi Mutubusa 


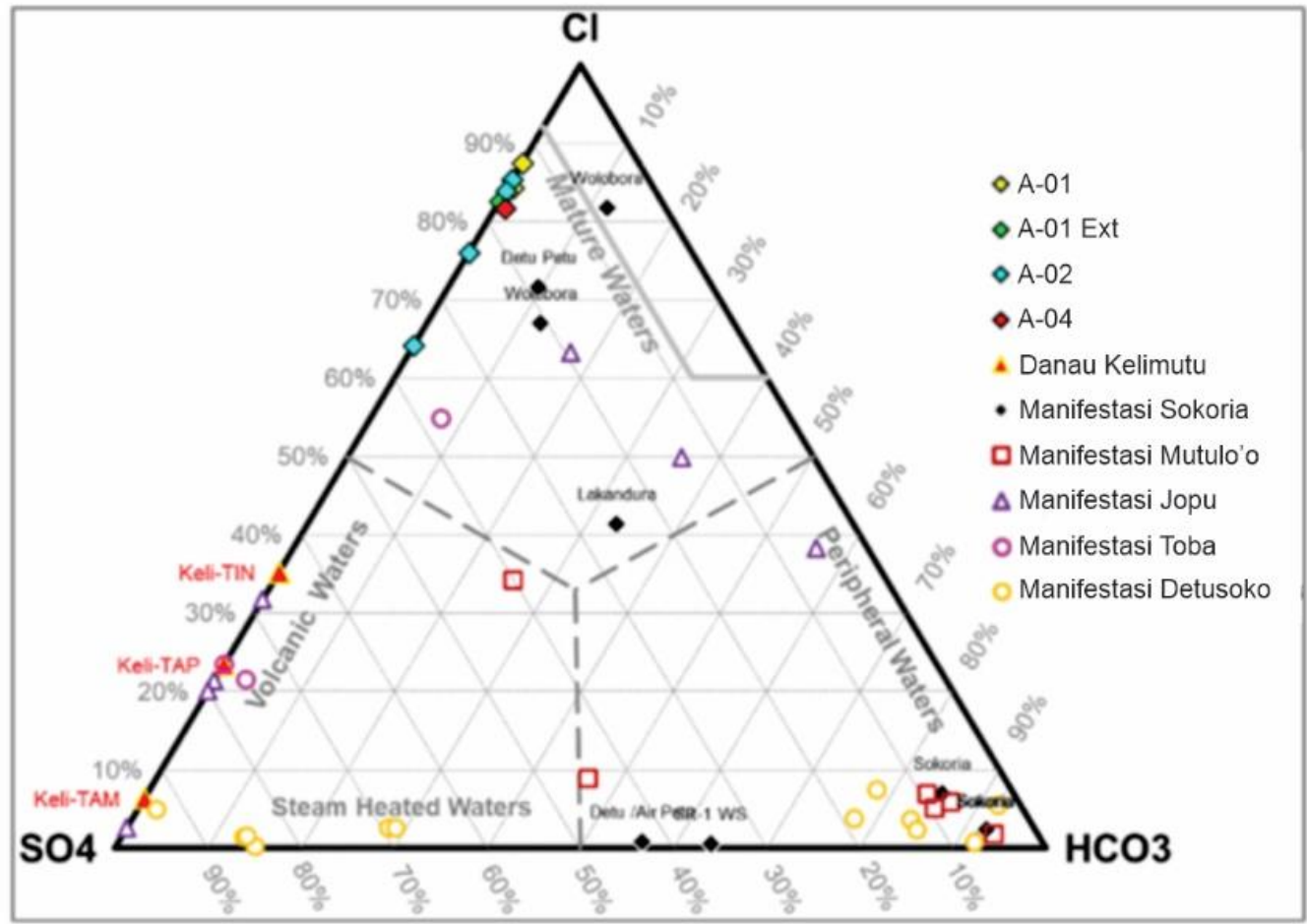

Gambar 4. Diagram ternary Cl-SO4-HCO3 dari Giggenbach, 1991

(Modifikasi dari Sarmiento et al., 2019)

\section{METODE}

Data petrografi yang digunakan pada penelitian ini berasal dari serbuk bor (core cutting) sumur eksplorasi W-1 dan W-2 untuk mengetahui mineral ubahannya dikombinasi dengan data hasil analisis pengukuran metilen biru $(M e B)$ serta uji tekanan dan temperatur ( $P \& T$ Test) pada kedua sumur eksplorasi tersebut. Sumur $\mathrm{W}-1$ yang dibor hingga kedalaman $1338 \mathrm{mMD}$ dan sumur $\mathrm{W}$ 2 hingga $2200 \mathrm{mMD}$ pada 2018.

Pengamatan petrografi dilakukan pada sampel yang diasumsikan berada pada zona reservoar untuk mengetahui kemunculan mineral geotermometer temperatur tinggi penciri zona reservoar, contohnya, epidot yang muncul pada temperatur $>220^{\circ} \mathrm{C}$ (Reyes, 2000).

Pengukuran MeB pada serbuk bor dilakukan untuk mengetahui persentase dari rasio ilitsmektit dalam batuan yang digunakan dalam interpretasi batas zona penudung ( $\mathrm{MeB}>$ $20 \%$ ), transisi (MeB $10-20 \%$ ), dan reservoar (MeB < 10\%) mengacu pada Grim (1953).
Tabel 1. Sensitivitas MeB dengan mineral teralterasi (Modifikasi dari Grim, 1953)

\begin{tabular}{ccc}
\hline $\begin{array}{c}\text { Mineral } \\
\text { Alterasi }\end{array}$ & $\begin{array}{c}\text { Persentase } \\
(\%)\end{array}$ & $\begin{array}{c}\text { Sensitivitas } \\
\text { MeB }\end{array}$ \\
\hline $\begin{array}{c}\text { Smektit } \\
\text { Mixed } \\
\text { Layer } \\
\text { Ilit- }\end{array}$ & $2--150$ & $\begin{array}{c}\text { Menengah - } \\
\text { Tinggi }\end{array}$ \\
$\begin{array}{c}\text { Smektit } \\
\text { Ilit }\end{array}$ & $0-10-20$ & Rendah \\
\hline
\end{tabular}

Uji P\&T dilakukan pada saat pemboran sumur adalah tahap yang paling penting dalam proses eksplorasi dan pengembangan panas bumi. Uji ini untuk mengetahui kondisi tekanan dan temperatur reservoar. Hasil data P\&T digunakan untuk interpretasi batas zona penudung, transisi dan reservoar.

\section{HASIL DAN PEMBAHASAN}

\section{Karakteristik Sumur W-1}

Pengamatan pada sayatan tipis $\mathrm{W}-1$ 1119 dengan variasi butiran dengan 


\section{MAKALAH ILMIAH}

warna tidak berwarna - kehijauan, sebagian butiran dengan tingkat alterasi lemah sedang, ukuran butir halus - sedang, pemilahan buruk, bentuk butir menyudut hingga membundar tanggung. Batuan di dominasi oleh tuf kristal $( \pm 90 \%)$, fragment mineral kuarsa $(3 \%)$, plagioklas $(2 \%)$ yang sebagian teralterasi menjadi mineral karbonat. Matriks tuf halus umumnya diidentifikasi sebagai lempung.

Tuf kristal, berwarna coklat kehijauan, sudah mengalami alterasi dengan ubahan lemah sedang, ukuran butir halus - sedang, kemas tertutup, pemilahan buruk - sedang, terdiri atas mineral plagioklas, segar- teralterasi, mineral opak dan matrik lempung, gelas dengan ubahan mineral klorit dan epidot (Gambar 5). Mineral plagioklas nampak berbentuk prismatik.
Komponen mineral kuarsa tidak berwarna, relif rendah, warna interferensi rendah, hadir sebagai kristal tersendiri dengan ukuran sedang, menunjukkan pemadaman yang bergelombang; Kuarsa sekunder, hadir kadang memotong butiran batuan, tekstur polikristalin dengan tekstur saling mengikat. Butiran mineral plagioklas tidak berwarna, anhedral, relif rendah, nampak kembar albit, sebagian terubah menjadi serisit dan lempung.

Epidot berwarna hijau-transparan, relief tinggi, anhedral. Hadir sebagai ubahan plagioklas maupun akibat larutan hidrotermal. Mineral karbonat tidak berwarna, relif tinggi, anhedral, warna interferensi tinggi, berbentuk agregat halus dan kasar, hadir sebagai ubahan plagioklas.

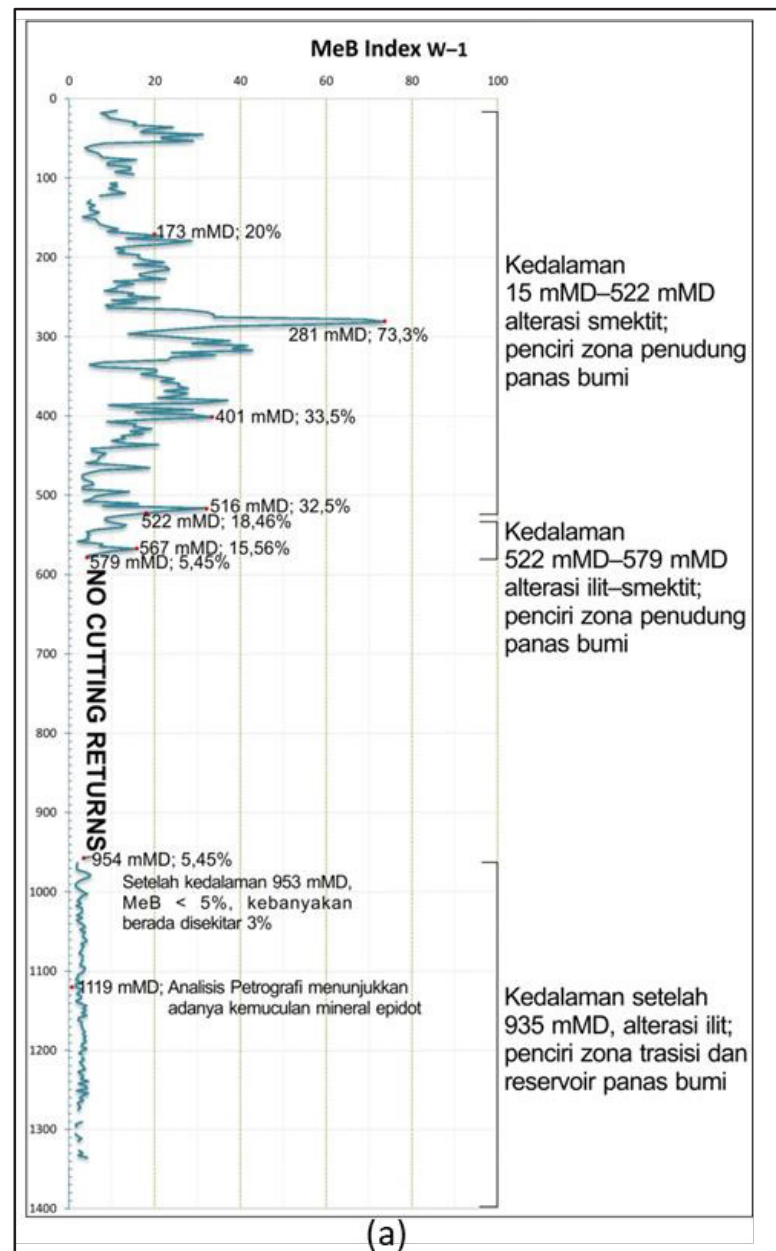

(a)

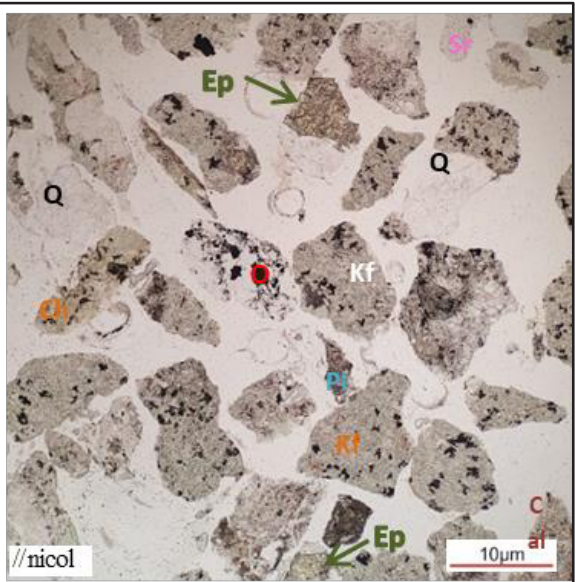

(b)

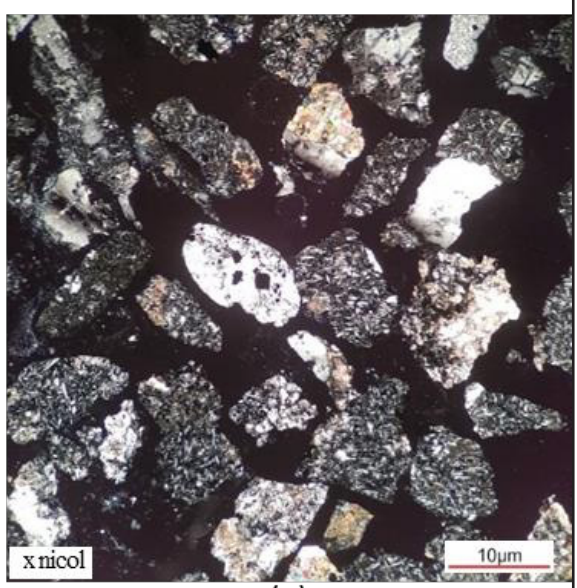

(c)

Gambar 5. (a) Indeks MeB W-1; (b) dan (c) Sayatan tipis sampel W-1 1119; terdapat epidot (Ep), Tuf kristal (Kf) dan mineral opak (O) 
Analisis MeB pada sumur W-1 menunjukkan pada kedalaman 173 mMD, indeks MeB meningkat dari $20 \%$ hingga puncaknya $73,3 \%$ di kedalaman $281 \mathrm{mMD}$ lalu menurun hingga $23,79 \%$ di 519 mMD. Indeks MeB 18,46\% pada kedalaman 522 $\mathrm{mMD}$ dan semakin menurun hingga $15,56 \%$ di kedalaman 556 mMD. Lalu pada kedalaman $570 \mathrm{mMD}$ - $579 \mathrm{mMD}$, indeks MeB yang didapat adalah sangat rendah, yaitu $<10 \%$. Pada kedalaman $581 \mathrm{mMD}-$ 953 mMD terjadi TLC (total loss circulation) yang mengakibatkan ketidakhadiran serbuk bor. Hal ini diduga akibat adanya struktur geologi. Pada kedalaman 954 mMD hingga $1338 \mathrm{mMD}$, indeks MeB yang didapat adalah sangat rendah, yaitu $<10 \%$, kebanyakan berada disekitar 3\%.

\section{Karakteristik Batuan di Sumur W-2}

Hasil pengamatan petrografi pada sayatan W-2 1338 menunjukkan epidot muncul pada kedalaman 1338 mMD pada batuan tuf kristal (Gambar 6) dan termasuk kedalam zona alterasi propilitik (Corbett, G.J., and Leach, T.M., 1998).

Komponen batuan terdiri dari tuf kristalf (94\%), berwarna coklat kehijauan, sudah mengalami alterasi sedang - kuat, ukuran sedang - kasar kemas tertutup, sortasi buruk - sedang, grain supported, komposisi utama berupa mineral plagioklas segar $(50 \%)$ dan juga klorit. Mineral plagioklas memiliki bentuk euhedral subhedral.

Komponen lain terdiri dari butiran mineral lempung $(2 \%)$, warna kecoklatan, ukuran halus, hadir mengubah seluruh batuan dengan sedikit veinlet karbonat dan butiran mineral epidot (4\%), berwarna hijau, kekuningan, relif tinggi, anhedral, warna interferensi sedang (kuning hingga pink), hadir mengubah butiran tersendiri.

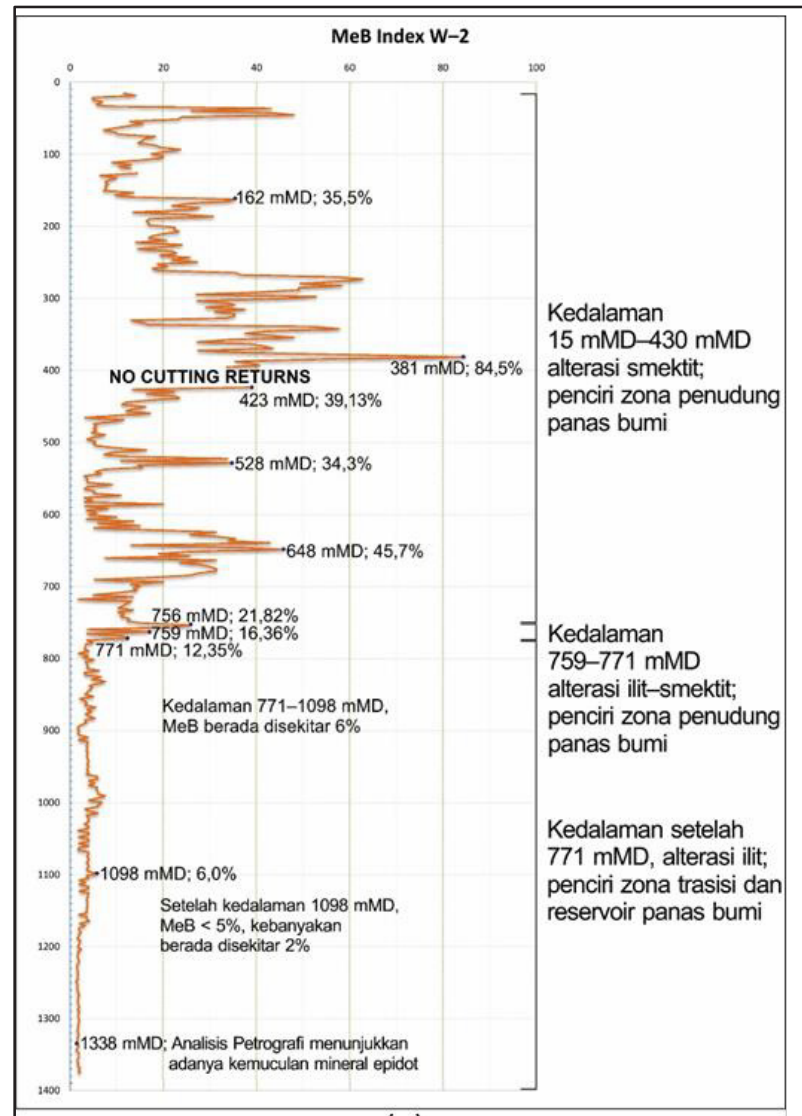

(a)

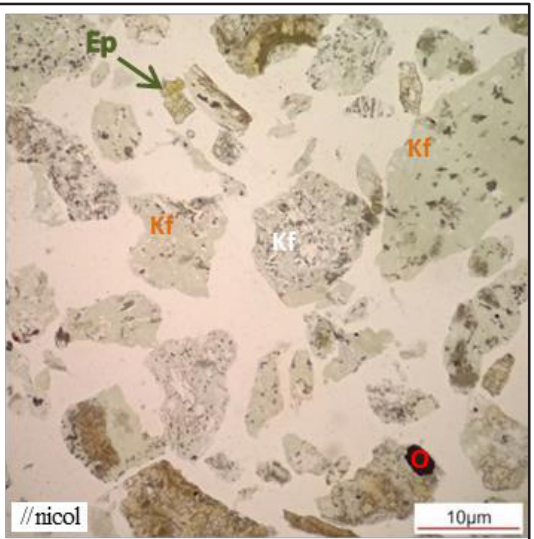

(b)

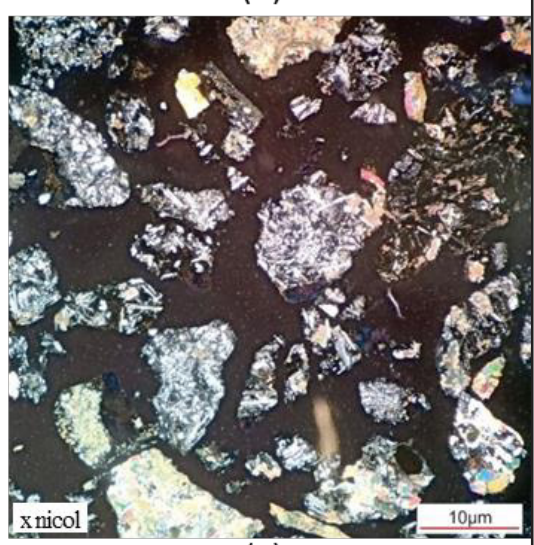

(c)

Gambar 6. (a) Indeks MeB sumur W-2; (b dan c) Fotomikrograf sampel W-2 1338 menunjukkan kehadiran mineral epidot (Ep), butiran tuf kristal (Kf) dan mineral opak (O) 
Analisis MeB pada sumur $\mathrm{W}-2$ menunjukkan di kedalaman $15 \mathrm{mMD}$ - $756 \mathrm{mMD}$ memiliki variasi indeks MeB sedang hingga tinggi (20 85\%). Pada kedalaman $759 \mathrm{mMD}-771 \mathrm{mMD}$ memiliki variasi MeB rendah (10 - $20 \%)$. Pada kedalaman setelah $771 \mathrm{mMD}$, indeks MeB sangat rendah $<10 \%$, yang kandungannya semakin menurun seiring bertambahnya kedalaman.

\section{Uji P\&T}

Pada pemboran menunjukkan ketidakhadiran cutting returns karena TLC di kedalaman 581 - 953 mMD yang diperkirakan akibat adanya struktur geologi Sesar Leledala. Temperatur sumur $\mathrm{W}-1$ mencapai $230^{\circ} \mathrm{C}$ di kedalaman $900 \mathrm{~m}$ dan tekanan awal yang mencapai 700 Psi.

Sumur W-2 dibor hingga kedalaman 2200 mMD dan log P\&T dilaksanakan pada Februari 2018. Laporan pemboran menunjukkan keberadaan TLC di kedalaman 1300 - 1500 mMD karena struktur Leledala. Feed zone utama sumur ini diperkirakan berada diantara kedalaman 900 - 1914 mMD, ditandai oleh terjadinya kick pada log temperatur di kedalaman 948 mMD dan 1350 $\mathrm{mMD}$, serta temperatur yang menstabil dan meningkat dikedalaman selanjutnya. Formasi temperatur sumur $\mathrm{W}-2$ mencapai $250^{\circ} \mathrm{C}$ di kedalaman $1900 \mathrm{~m}$ dan tekanan awal yang mencapai 1400 PSIA.

\section{Zona Alterasi}

Analisis petrografi pada sayatan W-1 1119 menunjukkan epidot pertama muncul pada kedalaman 1119 mMD pada batuan tuf kristal. Kehadiran epidot mencirikan telah terjadi perubahan akibat temperatur tinggi dan termasuk kedalam zona alterasi propilitik (Corbett, G.J., and Leach, T.M., 1998). Mineral epidot mencirikan temperatur pembentukan $>220^{\circ} \mathrm{C}$ (Reyes, 1990).

Analisis MeB pada sumur $\mathrm{W}-1$ dilakukan setiap interval $3 \mathrm{~m}$, dimulai dari $15-1341$
mMD. Dari gambar 4.a dapat diketahui, pada kedalaman $15 \mathrm{mMD}-519 \mathrm{mMD}$ memiliki variasi indeks $\mathrm{MeB}$ sedang hingga tinggi $(20-70 \%)$.

Zona alterasi yang dapat diidentifikasi di sumur eksplorasi W-1 dan W-2 lapangan panas bumi Sokoria terdiri dari zona alterasi smektit, ilit, dan ilit-epidot (Gambar 7).

Zona alterasi smektit berada pada kedalaman dari permukaan hingga 780 $\mathrm{mMD}$, dicirikan oleh variasi indeks $\mathrm{MeB}$ sedang hingga tinggi $(20-85 \%)$ sebagai penciri mineral lempung teralterasi smektit dan indeks MeB rendah $(10-20 \%)$ merupakan penciri mineral lempung teralterasi campuran ilit - smektit. Kemunculan smektit dan ilit - smektit mengindikasikan temperatur formasi batuan $<180^{\circ} \mathrm{C}$. Bagian bawah zona ini dikarakteristikan oleh menurunnya indeks MeB, $12,35 \%$ di kedalaman 771 mMD sumur $\mathrm{W}-2$.

Zona alterasi ilit berada pada kedalaman 780 - 1100 mMD, dicirikan oleh variasi indek MeB sangat rendah (< $10 \%$ ) penciri mineral lempung ilit. Kemunculan ilit mengindikasikan temperatur formasi batuan $200-240{ }^{\circ} \mathrm{C}$. Bagian bawah zona ini dicirikan oleh menurunnya kandungan ilit seiring bertambahnya kedalaman.

Zona alterasi ilit-epidot berada pada kedalaman > $1100 \mathrm{mMD}$. Zona ini dicirikan oleh kemunculan epidot (mineral teralterasi bertemperatur tinggi $>220{ }^{\circ} \mathrm{C}$ ) dari hasil analisis petrografi pada kedalaman 1119 mMD di sumur $\mathrm{W}$ - 1 dan pada kedalaman 1338 mMD di sumur W -2 serta indeks MeB sangat rendah $(<10 \%)$ penciri mineral lempung ilit. 


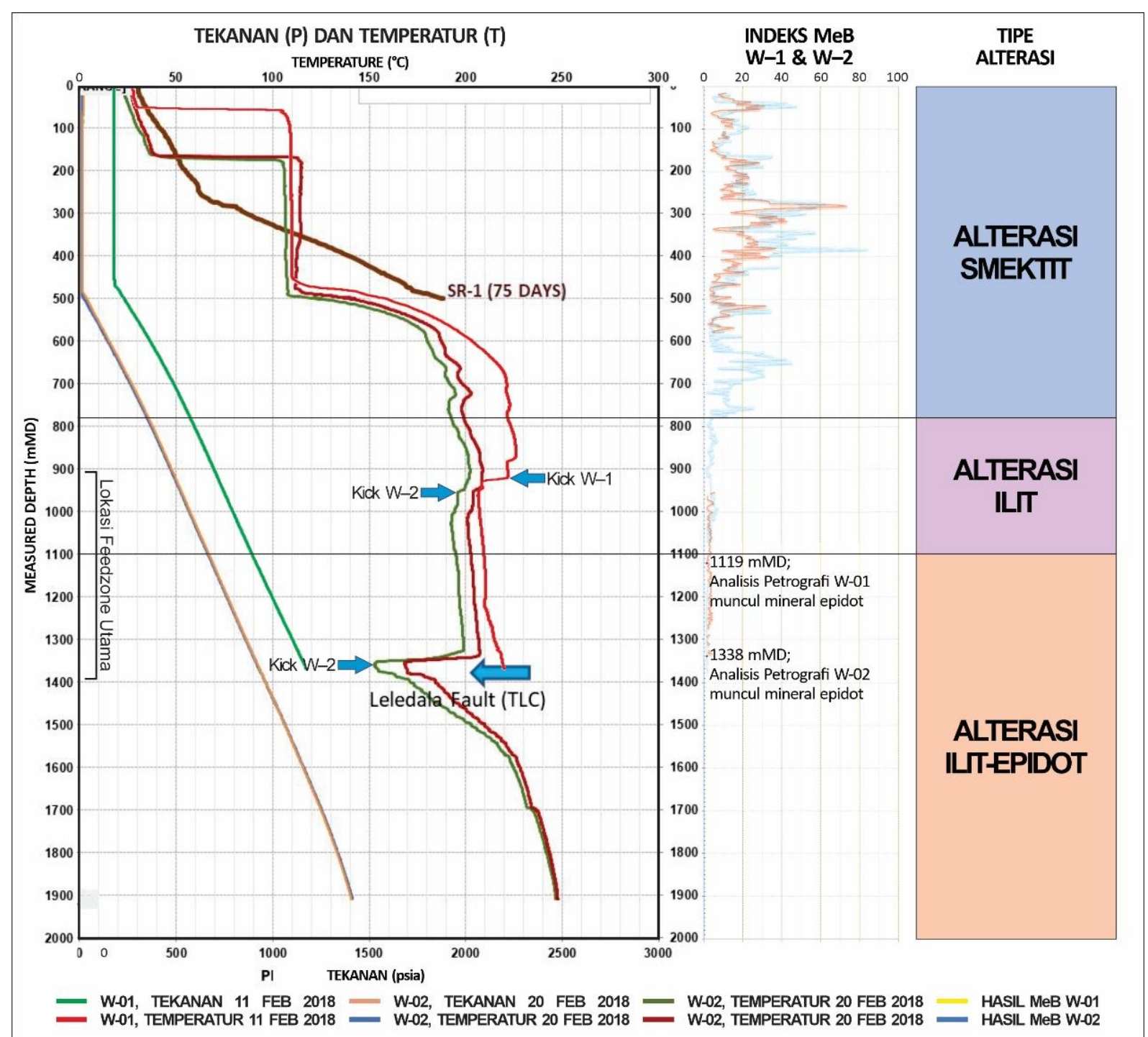

Gambar 7. Zona Alterasi pada sumur W-1 dan W-2 dari data uji P\&T, analisis MeB dan petrografi, menunjukkan dari permukaan - $780 \mathrm{mMD}$ adalah alterasi smektit, 780 - 1100 mMD adalah alterasi ilit, dan > 1110 mMD adalah alterasi ilit-epidot

\section{Korelasi Sumur}

Hasil dari korelasi sumur W-1 dan W-2 pada wellpad A memperlihatkan model tentatif geologi bawah permukaan panas bumi yang terdiri dari zona penudung, zona transisi, dan zona reservoar (Gambar 8).

Berdasarkan model tentatif geologi bawah permukaan tersebut, zona ubahan atau alterasi hidrothermal terdiri dari zona alterasi argilik (zona penudung sistem panas bumi), zona transisi argilik-propilitik (zona transisi sistem panas bumi), dan zona propilitik (zona reservoar sistem panas bumi).
Zona alterasi argilik dicirikan oleh indeks MeB rendah hingga tinggi (penciri mineral lempung smektit dan campuran ilit-smektit), 73,3 \% pada kedalaman 281 mMD sumur $\mathrm{W}-1$ dan $84,5 \%$ pada kedalaman $381 \mathrm{mMD}$ sumur $\mathrm{W}-2$. Bagian bawah zona ini dikarakteristikkan oleh menurunnya indeks MeB, $15,56 \%$ pada kedalaman 567 mMD sumur $\mathrm{W}-1$ dan $12,34 \%$ pada kedalaman 771 mMD sumur W-2. Kemunculan smektit dan ilit-smektit mengindikasikan temperatur formasi batuan $<180^{\circ} \mathrm{C}$. 


\section{MAKALAH ILMIAH}

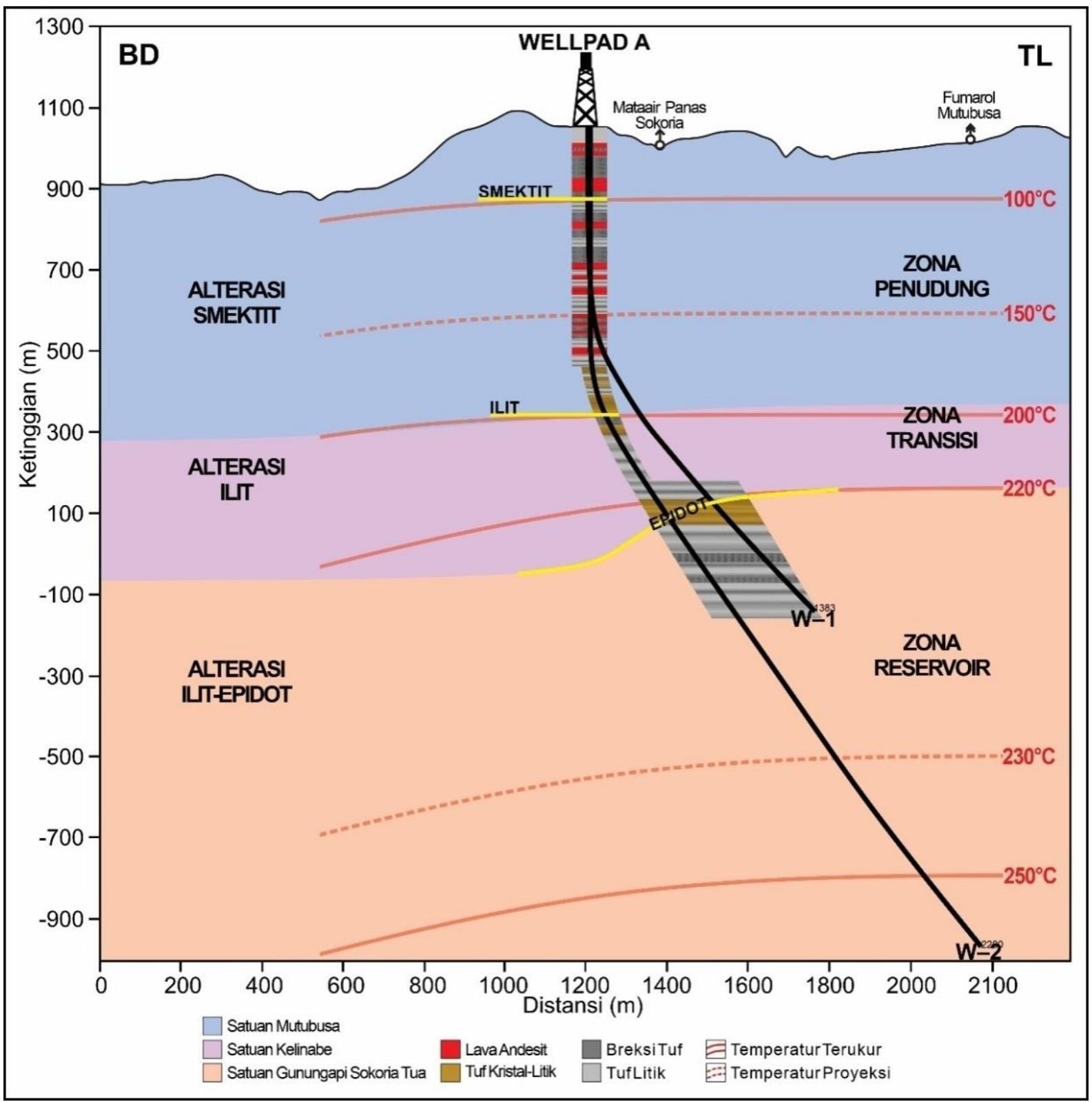

Gambar 8. Korelasi Sumur W-1 dan W-2 (Modifikasi dari Sarmiento et al., 2019)

Zona alterasi transisi argilik-porpilitik dicirikan oleh indeks MeB sangat rendah, penciri mineral lempung ilit; $5,45 \%$ pada kedalaman 954 mMD sumur $\mathrm{W}-1$ dan $6,0 \%$ pada kedalaman 1098 mMD sumur W-2. Bagian bawah zona ini juga dicirikan oleh menurunnya kandungan ilit (sekitar 6\%) seiring bertambahnya kedalaman; terlihat dari indeks MeB 6\% di sumur W-2 kedalaman 1098 mMD.

Zona alterasi propilitik dicirikan oleh kehadiran mineral ubahan epidot yang terbentuk pada temperatur tinggi $>220^{\circ} \mathrm{C}$ (Reyes, 2000) bersama mineral klorit, yang didapatkan dari analisis petrografi pada sayatan sumur W-1 kedalaman 1119 mMD dan W-2 kedalaman 1338 mMD.Selain itu, zona ini ditandai oleh indeks MeB sangat rendah $<10 \%$, penciri mineral lempung ilit. Kemunculan ilit mengindikasikan temperatur formasi batuan berkisar antara $200-240^{\circ} \mathrm{C}$.

Berdasarkan karakteristik di atas, dapat diinterpretasikan bahwa dari permukaan - 700 mVD merupakan zona alterasi argilik dan merupakan zona penudung 
sistem panas bumi lapangan Sokoria. Kemudian kedalaman 700 mVD - 1000 mVD merupakan zona transisi alterasi argilik propilitik dan merupakan zona transisi sistem panas bumi lapangan Sokoria. Dan kedalaman > 1000 mVD merupakan zona alterasi propilitik dan merupakan zona batuan reservoar utama sistem panas bumi lapangan Sokoria.

\section{KESIMPULAN}

Penggunaan metode MeB dipandu dengan analisis petrografi dan uji P\&T dapat digunakan sebagai petunjuk untuk pembagian zonasi penudung, transisi dan reservoar pada sistem panas bumi Sokoria. Pendugaan temperatur reservoar hasil uji P\&T diperoleh nilai antara $200-240^{\circ} \mathrm{C}$.

\section{UCAPAN TERIMAKASIH}

Penulis menyampaikan terima kasih kepada pimpinan PT. KS Orka Renewable Ltd. yang telah membantu saat pengambilan sampel dan penggunaan data untuk dipublikasikan.

\section{DAFTAR PUSTAKA}

Corbett, G.J., and Leach, T.M., 1998. Southwest Pacific gold-copper systems: Structure, alteration and mineralization. Soc. Econ. Geol. Special Publication 6, 238p.

Harvey C, Anderson, E., Johnstone, R., Christyono, 2000. Coexisting Volcanism and Hydrothermal Activity at Kelimutu, Flores Island, Eastern Indonesia, Proceeding of World Geothermal Congress, Kyushu-Tohoku, Japan.

Harvey C, Anderson, E., Johnstone, R., Christyono, 1998. Sokoria, East Indonesia: A Classic Volcano Hosted Hydrothermal System, Proceeding of $20^{\text {th }}$ NZ Geothermal Workshop.

Hochstein, M.P., Simanjuntak, J., Sudarman, S., 2010. Geothermal Prospects of the Eastern Banda Arc Islands (Indonesia). Proc WGC.
Giggenbach, W., 1991. Chemical techniques in geothermal exploration. Appl. Geochem. Geotherm. Reserv. Dev. 119-144.

Grim, R.E., 1953. Clay Mineralogy, International series in the earth sciences. McGraw-Hill.

Nicholson, K., 2012. Geothermal fluids: chemistry and exploration techniques. Springer Science \& Business Media.

Reyes, A.G., 2000. Petrology and mineral alteration in hydrothermal systems: From diagenesis to volcanic catastrophes. United Nations University, Geothermal Training Programme.

Reyes, A.G., 1990. Petrology of Philippine geothermal systems and the application of alteration mineralogy to their assessment. J. Volcanol. Geotherm. Res. 43, 279-309.

https://doi.org/10.1016/03770273(90)90057-M

Sarmiento, Z.F., Sagala, B., Siagian, H., 2019. The Sokoria Geothermal System, Flores Island, Indonesia. Geothermics 82, 282-295.

Suparman, S., 2009. Sumur Injeksi Mt-6 Di Lapangan Panas Bumi Mataloko, Kabupaten NgadaNusa Tenggara Timur. Bul. Sumber Daya Geol. 4, 58-67.

van Bemmelen, R.W., 1949. The Geology of Indonesia: General Geology of Indonesia and Adjacent Archipelagoes, the East Indies, Inclusive of the British Part of Borneo, the Malay Peninsula, the Philippine Islands, Eastern New Guinea, Christmas Island, and the Andaman and Nicobar Islands. Martinus Nijnhoff, the Netherlands.

\begin{tabular}{|ll|}
\hline Diterima & $: 6$ Desember 2019 \\
Direvisi & $: 31$ Maret 2020 \\
Disetujui & $: 31$ Agustus 2020 \\
\hline
\end{tabular}

